No. 1). The analysis and C.I.P.W. norm of the " argillite" are similar to, but differ in certain respects from, the analysis and C.I.P.W. norm of the olivine-bearing hornfels (see Phillips, 1959, Table 1, No. 4, and this letter Table 1, No. 2). The composition differs, however, no more than one would expect a portion of a pillow (perhaps slightly contaminated with migrating interpillow calcic material) to differ from a more fortuitously selected sample of basic rock collected some 150 yeards across the strike of a basic metavolcanic succession. Because of this, the idea that the contact metamorphism was practically isochemical is still the favoured hypothesis, and because of the new field evidence the relationship between hornfels and source rocks is a much simpler and more credible one.

Finally, I would like to say that at all times Associate Professor J. F. G. Wilkinson of the University of New England, thought from chemical evidence, without having seen the contact area, that the hornfels had been formed from some kind of basaltic rock, and I would like to thank him and Professor Wilson for the help they have given me.

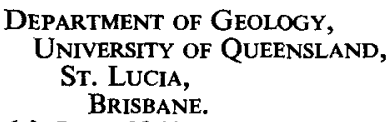

Evan R. Phillips.

\author{
REFERENCE \\ PhILlips, E. R., 1959. An Olivine-bearing Hornfels from South-Eastern \\ Queensland. Geol. Mag., 96, 377-384.
}

\title{
AN EARLY REFERENCE TO ISOSTASY
}

SIR,-The " Examination of Dr. Woodward's Account of the Deluge etc." is a rare pamphlet written by Dr. J. Arbuthnott and printed in London in 1697. The result of this " Examination "was very unfavourable to Dr. Woodward. In elegant language Arbuthnott, renowned wit, accomplished satirist and collaborator with Pope, Swift, and Gay, utterly demolished Woodward's edifice.

It will be remembered that, notwithstanding a denial of his obligation to postulate the origin of the waters of the Flood, Woodward did in fact claim that it came out of an internal cavity or abyss at the centre of the earth. It was this vacant hollow which excited Arbuthnott's interest. Nor is this surprising when we recall that this space had to remain empty until it was roofed by the reformed solid crust and to provide the receptacle into which the flood waters were to descend again when they had completed their business of temporarily transforming the earth into a thick suspension of earthy matter.

By a straightforward calculation based upon the reasonable assumption that there would be required at least a bulk of water equal to that of solid matter if any reasonable degree of fluidity of the mixture was to be achieved, Arbuthnott computed that the volume of water needed would envelop the earth to a depth of 450 miles. This quantity of water would occupy a sphere of 5,000 miles diameter with a centre coincident with that of the earth. Had he taken the modern estimate of the earth's radius in place of the then current figure of 3,600 miles his figures would have been increased by some 10 per cent.

The difficulties attendant upon the support of a liquid shell above an empty space naturally occurred to Arbuthnott, but what is more interesting is what he has to say about a solid carapace arching over such a vacuity. It is necessary, however, to grant him what he did not specifically claim, namely that his remarks would apply equally had this space been filled with a heavy fluid. Now, Woodward had interpreted horizontal planes of stratification as interfaces between concentric shells of materials of increasing density towards 
the centre of the earth and formed by settlement of disaggregated particles from a suspension. Writing of bedding planes formed in this way, Arbuthnott proceeds:

"I shall beg leave to add one reason why I think they would not be smooth a-top, and that is . . to make them smooth [i.e. planar] each solid Column, or to speak more properly, each truncated Sector must have been of the same bulk and the Matter of the same density; of the same bulk, else there would have been outward or inward Inequalities, where there was a difference in Extension; and of the same density, else the several columns could not balance themselves exactly in the subsidence, but one would have been higher than the other; both then would have provided Mountains and Valleys. Now since there were antediluvian Mountains it would seem that the Columns of the Earth had not been made up of Matter with both the aforementioned Properties."

Thus Arbuthnott stated the conditions for the existence of a perfectly uniform spherical shell forming the outer skin of a uniform sphere containing a concentric perfect spherical cavity. He recognized that the surface of this inner sphere constituted what a modern geophysicist would call the surface of compensation and that mountains and valleys could occur above it if they formed the summits of columns of different density. This corresponds to Pratt's isostatic model. He also came near to Airy's conception of isostatic balance when he realized that sectors of equal density differing in bulk would result in "outward or inward Extensions". Had he replaced " or" by " and" the likeness to Airy's model would have been complete.

It is interesting to see how this penetrating critic thought along the same lines as the founders of the modern notions of isostasy, a century and a half before the basis of that fruitful conception was presented to geologists.

DePartment of Geology,

Frank HoDson.

UNIVERSITY OF SOUTHAMPTON.

27th June, 1961.

THE MAAM FAULTS, CO. MAYO

SiR,--Professor J. G. C. Anderson remarks (Geol. Mag., 1960, xcvii, p. 511) that the north-westerly swing of the Wenlockian strike west of Cregganbaun is not " undoubtedly" related to the Maam Faults. The map (PI. XIX) in a recently published paper on the Ordovician between Cregganbaun and Killary Harbour (Stanton, 1960) clearly shows them to be due to one and the same cause, the Maam Disturbance. As described in the paper, this is a north-westerly trending vertical shear zone at least 25 miles long with a dextral displacement of 1.7 to 3.5 miles. In the rigid Mweelrea Grits the Disturbance is represented by the Maam tear faults, but on passing into the incompetent slates and greywackes of the Glenummera Slates and Sheefry Grits the faults die out and are progressively replaced by a zone of flexure (c.f. the upper and lower boundaries of the Glenummera Slates). Here both strata and cleavage swing round to the north-west, the strata being attenuated and the regional cleavage being accentuated to the point of schistosity. The Wenlockian strata west of Cregganbaun cross the Maam Disturbance and are involved in the flexure ; hence their change of strike. The displacement of the Wenlockian caused by the flexure is rather more than 2 miles, which is normal for the Maam Disturbance.

Professor Anderson suggests that : "the Maam fractures in fact ... developed very late and may in fact be due to post-Carboniferous N.-S. Armorican compression ; the arcs, on the other hand, are pre-Carboniferous." Since the Maam Disturbance caused the simultaneous formation of both the Maam Faults and the Cregganbaun are this statement must be in error. In fact, the evidence from the Ordovician south of Cragganbaun indicates that the Maam Disturbance developed in step with the regional folding. To quote only two examples : there is no sign in the Sheefry Grits of distortion of the regional Caledonian cleavage such as would result from later large-scale 